\title{
In-Service Education Programmes For Secondary School Teachers And Students' Academic Performance: A Case Study Of Nyarugenge District In Rwanda
}

\author{
Mr. Harerimana Jean Paul, Mr. Ntahobavukira Boniface, Ms. Adegoke \\ Oyebimpe Toyin \\ Coordinator, School of EducationMount Kenya University RwandaP.O.BOX 5826 Kigali \\ Associate facultyMount Kenya University RwandaP.O.BOX 5826 Kigali \\ Head of department, PsychologyMount Kenya University RwandaP.O.BOX 5826 Kigali
}

\begin{abstract}
This study is entitled "In-service Education Programmes for Secondary School Teachers and Students' Academic Performance, A case study of Nyarugenge District, Rwanda ". The purpose of this study was to examine the effect of in-service education programmmes for secondary school teachers on students' academic performance in secondary schools of Nyarugenge District between 2008 and 2012 school years. This study used the ex post facto research design. This research tried to analyse the causal-comparative relationship between in-service education programmes for secondary school teachers and the students' academic performance. The target population was made of teachers and head of studies from secondary schools in Nyarugenge District which have concurrently ordinary and advanced levels, whose results were released in the last five years from 2008 to 2012 . The number of those schools targeted by this study was 10 secondary schools. The teachers and head of studies were 286. The respondents purposively sampled were 167 teachers and head of studies. Among them, 157 were teachers and 10 head of studies sampled from the target population. The study found out that there was an effect of in-service education programmes for secondary school teachers on the students' academic performance in the last five years. The in-service education programmes have not been effectively implemented between 2008 and 2012, and were not regular in all secondary schools. The study also found out that the majority of secondary school teachers were qualified; on the other hand it was found out that there is a number of teachers who were unqualified in the subjects they are teaching. The majority of schools did not have well equipped school libraries with updated books and laboratories with modern materials. Consequently, the students' academic performance in national examinations during the last five years (20082012) decreased in secondary schools in both ordinary and advanced level due to several factors: irregular inservice education programmes, unqualified teachers and lack of school facilities. The study concluded that there is an effect of in-service education programmes of secondary school teachers on the decreased students' academic performance in Nyarugenge District. The research recommended that the Ministry of Education should design, support and encourage different types of in-service education programmes in secondary schools. The district education office and the school management also were recommended to implement at a regular basis less expensive types of in-service education programmes in their schools. The successful implementation of in-service education programmes should be the benefit to all stakeholders in education and improve the students' academic performance in national examinations as well as teachers' performance in secondary schools.
\end{abstract}

Key words: In-service education, Qualified teachers, academic performance, Head of studies

\section{INTRODUCTION AND BACKGROUND TO THE STUDY}

After the genocide in 1994, Rwanda education sector has passed through a challenging situation such as the loss of competent teachers and rehabilitating destroyed or defective infrastructure in some parts of the country. This includes the replacement of furniture, equipment and educational materials destroyed during the war and genocide, rehabilitation and strengthening of education in science and technology, as well as providing adequate supplies of textbooks and relevant educational material in schools. To cope with those challenges, after the genocide many reforms in education sector took place to raise the low students' academic performance and to reshape education system which had broken down (Ministry of Education, 2006). The main challenging situation faced by policy-makers was the low students' academic performance in secondary schools after the genocide. According to Ministry of Education (2012), the national average of the students' performance in secondary schools in national examination between 2006 and 2010 was $60.8 \%$ for ordinary level students who 
are selected for joining senior four classes or advanced level, and $82.3 \%$ for advanced level secondary students who are qualified to obtain certificates of senior six achievements. The students' academic performance between those five year as shown by the Ministry of education was low. Therefore, the low academic performance in secondary schools is much felt in some provinces and districts in Rwanda. Nyarugenge District is one of the districts which are disappointingly affected by the declined performance in secondary schools. The low academic performance is the result of many factors related to teacher qualifications, pupil-teacher ratio, condition of the facilities (The World Bank, 2004).In all those cited factors, teachers play a key role in the reforms towards the best academic performance. It is said that quality teachers are single greatest determinant of students' academic performance. In their findings, Wei, Darling-Hammond, Andree, Richardson, and Orphanos (2009) find that teacher education, ability, and experience account for more variation in student achievement than all factors. Studies have found out that 40 to 90 percent of the difference in student test score can be attributed to the teacher quality. Efforts to improve on students' academic performance can succeed only by building the capacity of teachers to improve their instructional practice and the capacity of school systems to advance teacher learning (Wei et al., 2009). In education, researches have shown that teacher quality and school leadership are the very potent factors in raising students' academic performance. Mizell (2010) summed it all by saying that for teachers to be effective they continually expand their knowledge and skills to implement the best practices. A number of studies report that the more professional knowledge teachers have, the higher levels of students' achievement (Villegas-Reimers, 2003).Following light on quantity and quality issue, the Ministry for public service and labour (2009) reported that about 37.3\% of secondary school teachers with A2 level certificate teach in the secondary schools in Rwanda. This is an indication that all is not well with the quality of teachers that are recruited to teach at the secondary school level. Such category of teachers would not be teaching in secondary schools in the rest of the East African region. Rwandan new and experienced teachers have encountered challenges due to reforms linked to changes of the medium of instruction, subject content, new instructional method of teaching, advancement in technology, changes of laws, and procedures. Teachers have been shown to have an important influence on students' academic achievement and they also play a crucial role in education attainment because the teachers are ultimately responsible for translating reforms and policy into actions. Consequently, there is a need of teacher professional development due to the observable low academic performance. Teacher professional development is key component of coping with those challenges. Ministry of education has organised trainings, and some schools develop their teachers by giving them facilities to handle the challenge of low performance and others have not. So, the academic performance continues to differ from one district to another. This study therefore tried to investigate the state of in-service education programmes, the state of qualification of teachers, and the availability of school facilities in the line with the students' academic performance between 2008 and 2012 in secondary schools in Nyarugenge District of Rwanda.

\section{STATEMENT OF THE PROBLEM}

Considering the governmental human resource recruitment in education sector and training in secondary schools, the outcome or students' academic performance has been observed to be unequal. According to the Ministry of Education (2012), the national average of the students' academic performance in secondary schools in national examination between 2006 and 2010 was $60.8 \%$ for ordinary level students who are selected to join senior four class or advanced level, and $82.3 \%$ for advanced level secondary students who are qualified to obtain certificates of senior six achievements. The students' academic performance in national examinations as shown is low. So, the students' academic performance in Kigali city, which includes Nyarugenge District secondary schools is said to be low due to different factors linked to teacher qualifications, pupil-teacher ratio, condition of the facilities (The World Bank, 2004). The Rwanda education system is largely examination oriented. From one level to another level students must sit for national examinations. There are main five levels of education system in Rwanda. To exemplify, a student to move from primary education to ordinary secondary level sits for primary six national examinations, from ordinary level to advanced level, he sits for the national examination, in the last year of advanced level he also sits for national examination for certificate award.

In addition to that the students' performance in Rwandan education sector tends to be measured in terms of the number of students passing national examination and students who obtain certificates and scholarship for further studies, especially to higher learning institutions. Stakeholders in education are worried about factors that influence students' academic performance. According to Ministry of Education strategic plan 2010-2015, the increase in the education budget linked to the increased number of students that education sector seeks to serve, whilst also recognising the necessary inputs to ensure the students' performance. The performance and investment seems to be unequal over last five years (2006-2010). Staff disposition (teachers) in the country over five years (2007-2011) reveals that a significant number of teachers are unqualified to be teaching in secondary schools. A number of secondary school teachers have secondary school certificate which means that they are secondary school graduates who should not even be teaching in secondary schools (Ministry for Public Service 
and Labour, 2009). One wonders if the low performance would not be due to the quality of teachers that have been recruited to service in the education system. This research therefore investigated the state of in-service education programmes for secondary school teachers, the state of teachers' qualifications, the availability of school facilities for secondary school teachers, and its effect on the students' academic performance in secondary schools in Nyarugenge District of Rwanda between 2008 and 2012.

\section{THE PURPOSE OF THE STUDY}

The main objective of this study was to investigate the impact of in-service education programmes for secondary school teachers on the students' academic performance in Nyarugenge District between 2008 and 2012.

\section{Specific Objectives}

The research was guided by the following specific objectives:

1. To examine the state of in-service programmes in secondary schools in Nyarugege District between 2008 and 2012 and its impact on the academic performance.

2. To find out the ratio of qualified teachers to unqualified ones in secondary schools in Nyarugenge District and their contribution to the students' academic performance.

3. To investigate on the state of performance of the secondary school students in secondary schools in Nyarugenge District between 2008 and 2012.

\subsection{Research Questions}

To achieve the above objectives, this research provided the answers to the following research questions: 1. What is the state of in-service education programmes in secondary schools in Nyarugenge District between 2008 and 2012 and its impact on the students' academic performance?

2. What is the ratio of qualified to unqualified teachers in secondary schools in Nyarugenge District and their contribution to the students' academic performance?

3. What is the state of performance of the secondary school students between 2008 and 2012 in Nyarugenge District?

\section{Significance of the Study}

This research is important to all stakeholders in education. The results of the study will help the ministry of education as a decision maker to organize, and to provide policymakers, researchers with a teacherdevelopment research base that can lead to powerful professional learning, instructional improvement, and student learning and implement strategies for developing teachers towards better academic achievement in their schools. It will also help school administrators to discover the new strategies for teacher training and professional development if any, by learning what constitutes good academic performance of students in well performed schools. Lastly, teachers will be motivated by the research findings to update and upgrade their knowledge and skills for teaching practices in order to cope with changes for the better performance in their respective assigned teaching courses.

\section{Related Literature Review}

\section{THEORATICAL FRAMEWORK}

The theory adapted for this study is derived from the System's theory input-output model developed by Ludwig Von Bertalanffy in 1956. The theory, according to Koontz and Weihrich (cited in Martha 2005) postulates that an organized enterprise does not exist in a vacuum; it is dependent on its environment in which it is established. They add that the inputs from the environment are received by the organization, which then transforms them into outputs. As adapted to this study, teachers are inputs, with different training programmes they are professionally developed through the process of teaching and learning and their output is seen through students' academic performance. In addition the school facilities such as library, textbooks, laboratories are also resource inputs that enables the teaching-learning process in any school to reach the desired target. Robbins (cited in Martha 2005) argued that organizations were increasingly described as absorbers, processors and generators and that the organizational system could be envisioned as made up of several interdependent factors. System advocates, according to Robbins (cited in Martha 2005) have recognized that a change in any factor within the organization has an impact on all other organizational or subsystem components. Thus, the teachers as inputs has to be updated and upgraded in order to highly influence the teaching and learning process and to achieve the desired target which is the better students' academic performance.In the line of System's theory input-output model, Yoon, Duncan, Lee, Scarloss, and Shapley (2007) state that professional development affects student achievement through three steps. First, professional development enhances teacher's knowledge 
and skills. Second, better knowledge and skills improve classroom teaching. Third, improved teaching practices raise students' performance. This means that in-service education programmes, as inputs in any education system, are designed to enhance the professional knowledge, skills, and attitudes of educators so that they might, in turn, improve the teaching- learning process and classroom practices which will lead to the best students' academic performance. On the other hand, a direct link to student outcomes is necessary to determine what types of professional development activities are effective within specific contexts. Therefore, in-service teacher education programmes are linked to measurable outcomes in student performance.

\section{IN-SERVICE EDUCATION AND ACADEMIC PERFORMANCE}

According to Mizell (2010), when people use the term "in-service education," they usually mean a formal process such as a conference, seminar, or workshop; collaborative learning among members of a work team; or a course at a college or university. However, in-service education can also occur in informal contexts such as discussions among work colleagues, independent reading and research, observations of a colleague's work, or other learning from a peer. People often use other names, including staff development, teacher professional development, training, professional learning, or continuing education. Whatever the term, the purpose is the same - to improve learning for educators and students. No doubt, school systems and schools that organize professional development effectively achieve impressive results. $\mathrm{He}$ further added that professional development may occur in several ways: during the regular school day; at school, but before classes begin or after they end; after school on an educator's own time; during days, a school system sets aside solely for professional development; or during the summer and other school breaks. ... Most importantly, studies have shown that teaching quality and school leadership are the most important factors in raising students' academic performance. Professional development is the only strategy school systems have to strengthen educators' performance levels. Professional development is also the only way educators can learn so that they are able to better their performance and raise student achievement. This means that there is a need for all teachers to continually increase their knowledge about teaching-learning practices through the in-service teacher education programmes to cope with the changes in new technology and policies for achieving the best students' performanceIn all professions, new teachers and principals take years to gain the skills they need to be effective in their roles. The complexity of teaching is so great that one-third of teachers leave the profession within three years and 50\% leave within five years. Even experienced teachers confront great challenges each year, including changes in subject content, new instructional methods, advances in technology, changed laws and procedures, and student learning needs. Educators who do not experience effective professional development do not improve their skills, and student learning suffers (Ingersoll, cited in Mizell 2010). On the other hand, Casteel and Ballantyne (2010) argued that professional development should be linked to measurable outcomes in student performance, behavior, and/or achievement. A direct link to student outcomes is necessary to determine what types of professional development activities are effective within specific contexts. This means that the teachers' in-service education is a must for new and experienced teachers due to different changes at various levels of education: policies, technology, methodology, curriculums, and the content to be taught.Different studies have found out the impact of in-service education on the students' academic performance. Rahman, Jumani ,Yasmin Akhter , Chisthi , and Ajmal ( 2011), in their study about relationship between training of teachers and effectiveness, they concluded that teacher training was positively related to effective teaching. The results of this study also indicated that there is a significant co-relation between teachers training and student test result. In his research on professional development program using industry partnerships and student achievement, Sullivan (2008), from his quantitative investigation suggested enhanced students' academic performance in science if teachers participated in a professional development program involving industry partnerships. According to Robinson (2011), in his doctoral dissertation, teachers were asked to share one example of how their professional development during the 2009-2010 school years impacted their students' academic performance by describing the professional development focus and describing the evidence of impact on student achievement. Of the 139 respondents to this question, 53 teachers (38.1\%) shared answers fitting the category of specific instructional programs and topics that were most influential. Specific program opportunities were focused on professional development were training in mathematics. So, the researcher shows that the professional development programmes have influenced the students' performance in mathematics as revealed by teachers who were asked questions during this research. Therefore in this study, skilled and updated manpower plays a significant role towards a better academic achievement. Some schools, in order to be academically successful, have to organise and implement in-service education programmes to upgrade and update the skills and knowledge of teachers.In addition, Seton (2005) in her study about evaluating the impact of professional development, the study has confirmed other research studies, and the professional literature indicating that effective professional development is critical for teacher growth and student achievement. The results of this study also support the research literature indicating the importance of setting clear goals and planning professional development that aligns to the vision and the needs of the school district. One of the most 
significant findings of this study was the strong correlation between teachers reported implementation of new knowledge and skills in the classroom and the impact on student learning outcomes. On the other hand, Olaniyan and Ojo (2008) found that staff training and development are based on the premise that staff skills need to be improved for organizations to grow. Training is a systematic development of knowledge, skills and attitudes required by employees to perform adequately on a given task or job. New entrants into organizations have various skills, though not all are relevant to organizational needs. Training and development are required for staff to enable them work towards taking the schools to its expected performance.According to Nakpodia (2010), the result of the findings revealed that human resources undergo different forms of training. The result also revealed that there is a significance difference between the performances of human resources in relation to students' academic performance. It was therefore concluded that school personnel should undergo training and attend regular workshops and seminars. Also that the performance of human resources have considerable effects on students' academic performance. Robinson (2011), further, in the study on middle school teachers' perceptions of professional development experiences, found that teachers believed their professional development was aligned or strongly aligned with the items on the survey representing the standards. Teachers indicated that learning about specific instructional programs and collaboration with other teachers had the greatest impact on their classroom practices. Similarly, teachers indicated that learning about specific instructional programs and collaboration with other teachers had the greatest impact on their students' academic performance.Ngala and Odebero (2010) in their study revealed that the most popular staff development programmes are taking higher education and training, in-service courses and participating in workshops, seminars and conferences among others. During such programmes, teachers learn school management skills, evaluation techniques, academic achievement correlates and master wider content areas of their subjects. Teachers in the high performing schools were found to take more interest in staff development programmes compared to their colleagues in the average performing schools. Rahman et al. (2011), further stated in their study the ways in which teacher training was related to effective teaching in terms of students' performance. The purpose of the study was to assess relationship between teacher training and effective teaching. It was found that teachers had a positive attitude towards teacher training and its effectiveness in classroom situation including actual instruction/academic work, classroom management, evaluation procedures, assignments, and developing human relationships with students, principal, and society in general. It was concluded that teacher training was positively related to effective teaching. The results of the study also indicated that there is a significant co-relation between teachers training and student test result.

Akinfe, Olofinniyi and Fashiku (2012) investigated in their study on teachers' quality as correlates of students' academic performance in Biology in senior secondary schools in Ondo State, Nigeria, to guide the study, four research questions were raised. The multi-stage sampling technique was used to collect data from two hundred teachers (200) as respondents. The study revealed that the role of professionally qualified/trained teachers is an important teacher quality which enhances students' academic achievement in biology. The study also revealed that several schools in the population lacked modern instructional materials without which effective teaching and learning cannot be utilized and teachers' experience significantly influence students' academic performance, and concluded that capacity building forms a major aspect of teachers' experience that is yet to be given adequate attention. Its importance cannot be over emphasized in view of senior secondary school student's poor performance in both internal and external examinations.Gupta and Kashiri (2006) in the paper features a school district with successful collaborative effort with other educational organizations for providing professional development programs to build teacher capacity. Increasingly, his research confirms that teacher and teaching quality are the most powerful predictors of student success. By investing in teacher professional development, districts assure higher students' academic performance. On the other hand, SnowRenner and Lauer (2005) in their research indicate that professional development holds promise for improving students' academic performance. Changes in practice also depend on a sustained and targeted professional development focus on particular content knowledge and instructional strategies to have effects on teacher instruction and achievement. This means that the in-service teacher education has to be well planned and targeted. Therefore, the main target could be the content and the techniques that are used to deliver that content for having impact on the teaching achievement. In their research on the effects of California mathematics replacement units on reform-oriented instruction and student achievement, Cohen and Hill (cited in SnowRenner and Lauer 2005) noted that the content of what teachers learn is very important. They found that inservice education focused on specific curricula resulted in more reform-oriented practice than more general professional development. And reform-oriented teacher instruction was positively related to students' academic performance. Therefore, the teacher education programmes have to be focused on specific curricula or content instead of being general oriented to generate the meaningful students' academic results. The research we reviewed indicated a mixed relationship between standards-based in-service education and students' academic performance. When studies examine high-quality professional development into the equation (e.g., sustained duration and focus on content, active learning, coherence), a slight positive relationship can be seen. But this is 
highly dependent on the achievement measure. Even quasi-experimental studies, which are stronger in attributing achievement effects to professional development, may show different results, depending on the measure (Snow-Renner \& Lauer, 2005). This means that professional development provides ongoing opportunities for educators to continue to improve their knowledge and skills so they can help students' academic performance. Ball and Cohen (1999) argued that a significant number of studies identified as potentially addressing the effect of in-service education on students' academic performance. This report finds that teachers who receive substantial professional development - an average of 49 hours in the nine studiescan boost their students' achievement by about 21 percentile points. Professional development for teachers is a key mechanism for improving classroom instruction and student achievement. Therefore, a teacher achieves results and gains increased experience and examines his or her teaching systematically by experiencing teacher professional development at regular intervals. To improve professional learning for educators is a crucial step in transforming schools and improving academic achievement. Darling-Hammond, Andree, Richardson, and Orphanos (2009), in recent decades, school reform efforts have recognized in-service education as a key component of change and as an important link between the standards movement and students' academic performance. As students are expected to learn more complex and analytical skills in preparation for further education and work in the 21st century, teachers must learn to teach in ways that develop higher order thinking and performance. These new standards require a new kind of teaching, conducted by "teachers who understand learning as well as teaching, who can address students' needs as well as the demands of their disciplines, and who can create bridges between students' experiences and curriculum goals". Efforts to improve student achievement can succeed only by building the capacity of teachers to improve their instructional practice and the capacity of school systems to advance teacher learning. Consequently, to meet government expectations for school and student performance, the school needs to strengthen teacher skills and knowledge to ensure that every teacher is able to teach increasingly diverse learners, knowledgeable about student learning, competent in complex core academic content, and skillful at the craft of teaching. They further added that since the impact of teacher learning on students' academic performance may not be immediate, and measures of student learning gains that can be linked to specific professional development are often difficult to secure, interim measures that examine practice are valuable, especially where the practices in question have been shown to influence student achievement. Teachers who engaged in a structured dialogue to solve problems of literacy learning ultimately researched and adopted new practices which influenced students' academic performance.Pennsylvania State Education Association Education Services Division Research (2008) makes clear that" professional development experiences can impact student achievement and educator practice in positive way.Student learning outcomes - measures changes in student learning that can reasonably be attributed to professional development. Sources of evidence include test scores, attendance, quizzes, motivation, homework completion, and classroom behavior". This means that the best tools for measuring the effect of in-service teacher education on students' outcome with evidence are examination scores, test scores and grade scores, attendance, quizzes, students' motivation, and the change of behavior in the classrooms.

\section{TRAINING, WORKSHOP AND ACADEMIC PERFORMANCE}

Brown, Choi, and Thomas (2008) identified traditional structural features of professional development such as workshops, seminars, and should also be supplanted by new models such as mentoring, peer observation and coaching, networking, and collaborative work. When teachers collaborate research indicates an increase in their academic content, knowledge and increased direct communication about student performance. Rahman, Jumani ,Akhter, Chisthi , and Ajmal (2011) defined training as a processes designed to enhance the professional knowledge, skills, and attitudes of educators so that they might, in turn, improve the learning of students. Training is an important part of teacher preparation programs, especially for those aspects of teaching that are more skill-like in their conception, but there are many other important aspects of teaching that can only be nurtured through reflective strategies and experiences. Asu ( cited in Rahman et al. 2011) in his study found that teachers had a positive attitude towards teacher training and its effectiveness in classroom situation including actual instruction/academic work, classroom management, evaluation procedures, assignments, and developing human relationships with students, principal, and society in general. Students also had positive opinion about teachers general characteristics, clarity and effectiveness of presentation, developing student interest/involvement in learning, broadening student outlook, and developing good relationship with students, it was concluded that teacher training was positively related to effective teaching. This relationship was statistically significant and positive for overall students' academic performance. Bauer (cited in Rahman et al. 2011) pointed out the contrary view that student performance may be caused by any number of factors, including what's taught in schools, a student's native intelligence, and out-of-school learning opportunities that are heavily influenced by a students' home environment. The same is the case with the findings of this study. The results of the study concluded that there is significant co-relation between teacher training and students' academic performance. 
Akinfe, Olofinniyi , and Fashiku (2012) in their study also indicate that when teaching methods are effectively utilized, students' academic performance will increase tremendously and that teachers experience is an added advantage in preparing students for both internal and external examination. It was also established that the quality of teachers to a large extent determine students achievement because a professional teacher will make the best of every unpleasant situation; however, an enabling environment must be created in terms of instructional aids amongst other variables for the teachers' potentials to be utilized maximally. He concluded that there is need to review the teacher education and certification programme to enable it meet international educational standards at various levels of the educational process. The need to update teacher's knowledge on ways of teaching biology and acquaint them with other new innovations is also to be emphasized. This could be made possible by frequently organizing seminars, workshops and in-service training of teachers. Shah (2009) also stated that professional development of teachers is essential for qualitative improvement of any system of higher education. Professional development is concerned with development of knowledge and skill of the teachers. The individual is the main agency for professional development. The teacher can update his/her knowledge and improve his/her skill if he/she is sincere in effort and gets opportunity of development. The individual cannot be able to provide necessary facilities for skill improvement. With the price of books having escalated in recent years, it is beyond the reach of a teacher to have even a few books every month. He added that the institution is in a better position and take up the responsibility. All good institutions have good libraries. These also run occasional programmes for skill development bodies also work professional development of teachers. The institutions and other agencies undertake professional development activities because of the reasons such as (a) concern to improve the quality, (b) initiative by teachers to do research on teaching, (c) competition among institutions compelling the old to look for alternative and innovative methods of instruction and (d) diversified student population which is not satisfied by the uniform teaching methods and styles.

\section{PEER OBSERVATION AND STUDENTS' ACADEMIC PERFORMANCE}

According to Lancaster university Peer observation of teaching - Briefing Paper, the term peer observation of teaching is here used to mean the observation by colleagues of each other's teaching, usually but not always within a department, for the purpose of sharing practice, getting feedback and facilitating critical reflection on our practice. The observation process works best when it is seen as an opportunity for curriculum development and collaboration, where colleagues depart from a narrow scrutiny of 'performance' to a discussion of wider teaching and learning and course design issues, with due consideration of the contextual influences that combine to shape effective teaching and learning. Peer observation best fits within a systematic course review process that combines with a variety of other feedback sources, such as student feedback, assessment outcomes, student progression and performance.Byrne, Brown, and Challen (2000), stated the purpose of peer observation may be thought of as accounting for, and improving, the quality of teaching with the aim of improving student learning. As such, peer observation of teaching may have become a tool to measure teaching performance (or underperformance) and be used in the appraisal of individuals. Another additional view is that teachers need time and support to talk about teaching, reflect, and observe one another's classrooms on a weekly, if not daily, basis if they are to make lasting changes in their classroom practice. Teachers learn best from each other-from trial and error in the classroom, from talking to colleagues, from instructional coaches and leaders, and from doing this over the course of their careers. This kind of rich, school-based learning requires a profound shift in a school's culture. It also requires the resources of time and skilled coaching from internal and external leaders. The results are worth it (Mednick, 2004). Davys, McKenna, and Tickle (2008) found that the purpose of peer observation is to raise the quality of teaching and sharing good practice with colleagues. In general terms, it involves peers observing each other's practice with the aim of improving practice and facilitating personal and professional development.

\section{COACHING AND STUDENTS'ACADEMIC PERFORMANCE}

According to Lofthouse, Leat, and Towler (2010), coaching is usually focused professional dialogue designed to aid the coachee in developing specific professional skills to enhance their teaching repertoire. He added that through coaching teachers' learning and development underpins school improvement and provides a vehicle for raising performance and attainment. Teacher coaching in schools takes various forms, but is commonly conceived as a means of providing personalised professional support to teachers through discussion about their practice. Coaching takes time to organise and facilitate within any organisation, and as time is precious in all schools it is important that coaching, where used, works to maximum effect.Wong and Nicotera (2003) argued that peer coaching is one of many professional development strategies. The strength of peer coaching lies in its potential to promote a culture of collaboration and professionalism among teachers. It is also designed to improve the level of implementation of new instructional techniques and curriculum. Kinkead (2007) explained coaching as the release from the classroom of exemplary teachers on a full or part-time basis to work in partnership with experienced colleagues to accelerate professional learning. The spotlight is on 
content development and the instructional strategies used to enhance student learning and achievement. Instructional Coaches work to improve teachers' instructional strategies within content areas. Both kinds of coaches facilitate collaborative dialogue and the application of "best practices" to increase effective instruction and student learning. School-wide change takes time and sustained commitment. Deep changes in teacher practice occur through experience, reflection, collaboration, and continued learning. This requires sustained support for teachers and coaches. Success cannot be measured within a single school year, but over time the academic performance of students should improve as teachers refine their instructional practices.

According to Lofthouse, Leat, and Towler (2010), teachers' learning and development underpins school improvement and provides a vehicle for raising achievement and attainment. When teachers' learning is based on their genuine assessment and understanding of pupils' learning they can start to make adaptations to their practice which can lead to real differences in outcomes. Good coaching encourages teachers to become more reflective, articulate, and exploratory in relation to their work and its impact on learners. As such they are more aware of themselves and their capacities as teachers, more knowledgeable about the activity of teaching and the processes of learning, and more confident to deploy a wide pedagogic repertoire suited to the job. Cowie (2010) viewed coaching as a term that is used to describe a variety of activities from sports coaching, life coaching, leadership and executive coaching to team coaching in organisations. It is largely used when a person or organisation is working towards some change in growth and development, and improving performance. The term coaching is sometimes used synonymously with the term mentoring, although the terms are distinctly different and can be defined according to the specific activity that is taking place and the role of the players. Coaching is necessary when members are new or there has been a redevelopment of the core values. Change in schools is most often related to changes in practices and policy initiatives based on new research and findings.

Hanover (2012) stipulates that peer coaching may be an effective model of staff development," fewer studies have focused on the method's effect on student performance, and "many educators are asking hard questions about peer coaching and academic achievement." Although there are "increasing indications" in the literature that "coaching can affect academic performance," most of these studies have been examining situations in which peer coaching was one of several strategies being employed. Earlier studies showing improvements in students' academic performance were similarly based on comprehensive programs of which peer coaching was just one element. A 2003 review stated a contrary view that no study has proven that coaching contributes significantly to increased students' academic performance. However, part of the explanation is that there have been scant studies of this form of professional development and how it influences teachers' practice and students' learning. Instead of that, studies there have been able to establish a connection between peer coaching and student achievement.

\section{MENTORING AND STUDENTS' ACADEMIC PERFORMANCE}

Kinkead (2007) defined mentoring as the working relationship established between new/novice teachers (mentees) and experienced teachers (mentors). The primary focus of the mentor/mentee relationship is to strengthen the new teacher's understanding and initial application of subject area content, instructional practices, school processes and management strategies. Taylor and Francis (2011) argued that mentoring provides an excellent opportunity for individual professional advancement. Specifically for academic advancement, mentoring programs implemented in the context of higher education have been found to show positive effects for mentees, as well as for mentors and universities to achieve better academic performance. Bullock (cited in Abiddin 2006) was of the opinion that a mentor should establish a good rapport with his protégés, assess their needs in consultation with other interested and appropriate parties, and end the mentoring relationship at the appropriate time and in an appropriate manner. Thus, each mentoring arrangement is unique, and its particular nature will be established according to the personalities of the two individuals concerned. The relationship facilitates another's personal growth and can also encourage and enable learning in order to maximise the mentee's potential, develop their skills, improve their performance and become the person they want to be. The relationship should be dynamic. On the other hand, Dove (1986) was of the view that teacher effectiveness cannot sensibly be separated from school effectiveness. One aspect of this which is beginning to receive the attention of researchers and policy makers in developing countries is the level of school resources. Common sense suggest that teachers, however well educated and trained, are rendered less effective if school lacks the basic facilities, equipment and materials necessary for teaching and learning.

\section{TEACHER QUALIFICATION AND ACADEMIC PERFORMANCE}

Nakpodia (2010) in his study about the success of every educational system how it depends on the quality and quantity of its factors or production - human and material resources. Of all the factors, the human resource appears to be the most important because without human efforts, all other factors are useless. This is why it is necessary to train and re-train the staff of any organization for better production. He carried out this research in 278 public schools, consisting of 5,315 human resources in the state, out of which 3,904 are trained staff while 
1411 are untrained staff. The sample used for this study is made of male and female human resources of the sampled schools in Delta State, Nigeria. From the target population, a total of 56 schools, representing $20 \%$ of the total of 278 public schools, and 1,063 staff, representing $20 \%$ of the total of 5,315 human resources in the schools. Nakpodia concluded that the respondents agreed that the performance of human resources affect the students' academic performance, as most of the respondents believe that the trained staff is dynamic in the use of teaching techniques while the untrained staff is stereotyped in the use of teaching technique. In addition to that, the respondents also strongly agreed that the special teaching tools of the trained staff are the teaching methods, as most of the respondents believe that teaching methods bridge the gap during teaching. In view of the above, the researchers are of the view that the trained staff can use their abilities to influence students to performance while the untrained staff cannot, especially in the use of teaching techniques, methods and other teaching styles learnt as trained staff. The Rwanda education system has been characterized by different changes in policies and reforms due to the political power, globalization, and vision 2020.So, those changes were challenged by the shortage of qualified teaching staff which led to the students' poor academic achievement in many schools and inefficiency of manpower trained in those schools. This study reached at the conclusion that the professional development of any education system is very useful and influential to the academic activities. The trained staff is enough equipped with all necessary updated skills to cope with changes due to technology, new instructional methods and apply special teaching tools and techniques to influence students' achievement. The teaching staff is required to upgrade and update skills and knowledge in order to improve on their practices and students' results (Nakpodia, 2010).Agharuwhe and Ugborugbo (2009), in their study on the influence of teachers' classroom effectiveness on students' academic performance in public secondary schools in Delta State, Nigeria. It was descriptive in nature and involved 979 teachers, made up of 450 males and 519 females, drawn from 72 out of the total of 361 public secondary schools in the State by stratified random sampling technique. Academic performance records of 50 students per teacher, which is 48,950 students' scores were also used. Two questionnaires and a rating scale were used to collect data for the study. The study found that teachers who were rated as ineffective actually produced students of lower academic ability. Therefore, the secondary schools perform and score differently in both national and district examinations. The success rates differ from one school to another. The staff development and working conditions might be the reasons behind the noticeable failures in some schools. Thomas and Olugbenga (2012) revealed that students taught by teachers with higher qualifications performed better than those taught by teachers with lower qualifications. It was also showed that students performed better in physics when taught by professional teachers. Fakeye (2012), in the findings of his study showed that teachers' teaching qualification has a significant relative contribution to students' academic achievement in English language.Akinsolu (2010) showed teachers' qualifications, experience and teacherstudent ratio were significantly related to students' academic performance. Ukiri and Ugborugbo (2009) in their research showed that effective teachers produced better performing students. Academic qualification, professional qualification, refresher courses or trainings and teacher experience are the important qualities of a teacher. The qualities like academic qualifications and knowledge of the subject matter, competencies and skills, and the commitment of teacher have an impact on the teaching learning process.

\section{CONCEPTUAL FRAMEWORK}

This section proposes a conceptual framework within which the concept, academic performance is treated in this work. It is arrived at basing on the System's theory Input-Output model advanced by Ludwig Von Bertalanffy (cited in Martha 2005). The selection of the model is based on the belief that, the quality of input invariably affects the quality of output which, in this case, is students' academic performance.

Figure 1:. Conceptual framework

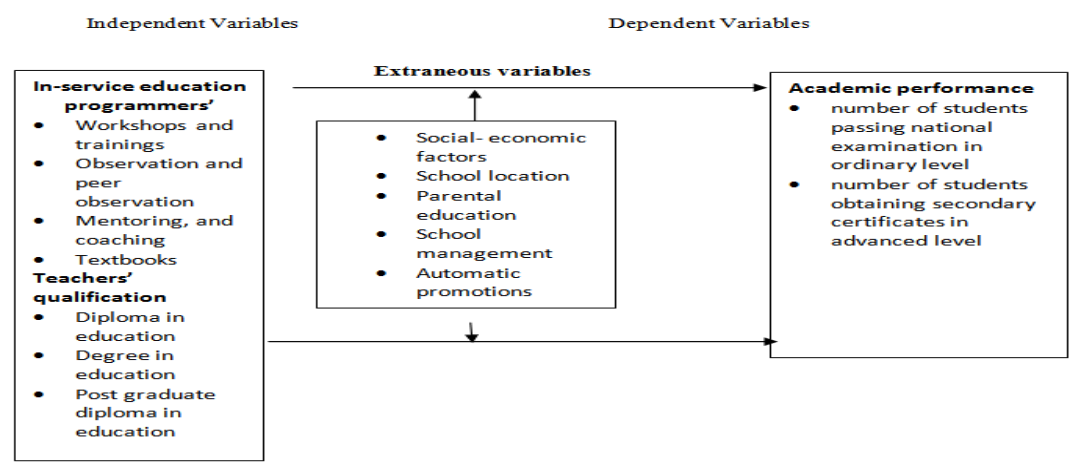

Source: Adapted from Martha (2005) 
Figure1 shows the relationship between different in-service educational programmes for teachers and students 'academic performance. It shows students' academic performance as a dependent variable which is related to the independent variables, which are in-service education programmes, school facilities, and teachers' qualifications. According to this figure various in-service educational programmes which includes, training; workshops, peer observation, coaching and mentoring are having an impact on students' academic performance. When the in-service education programmes introduced in any school, the higher students' academic performance is expected. The second independent variables are schools facilities that include library, laboratory, and school buildings. They also greatly influence the students' academic performance. The third independent variables that have impact on the students' academic performance are teachers' qualifications. Teachers' education level, skills and knowledge are the factors that increase and sharpen the students' academic performance. Figure1 also identified some extraneous variables, which may affect students' academic performance, these include, social- economic factors, school location, class size, parental education, School management, working conditions, and automatic promotions. These variables are part of the input and process explained in the Ludwig's Input-Output model. They play a role in bringing about the output, which is academic performance. If these variables are not controlled, they may interfere with the results of the study. The researcher controlled the effect of the extraneous variables by purposively selecting schools in the district to be the subject of the study. According to Amin (cited in Martha 2005) says that it is one of the ways to attempt to control many extraneous variables at the same time.

\section{Research Design}

The study used the ex post facto research design research design used was mixed methods approach. The researcher investigated on the causal-comparative relationship between in-service education and the students' academic performance.

\section{Target Population}

Population refers to the larger group to which a researcher wishes to generalize; it includes all members of a defined class of people, events, or objects (Ary, Cheser \& Sorensen 2006). The population of this study was the teachers and head of studies in Nyarugenge District and target population was the head of studies and teachers in secondary schools in Nyarugenge District. The number of schools targeted was the schools which have concurrently ordinary and advanced levels, and their results were released in the last five years (20082012). The secondary schools targeted were only 10 which contain public and private schools. So, the number of teachers and head of studies in those schools was 286 hundred. To cover all the population was not possible because of limited resources and time. That is why sampling techniques were applied.

\section{Sampling Technique}

The purposive sampling technique was used to select the head of studies of each school to be represented and random sampling for selecting teachers from 10 secondary schools in Nyarugenge district. Table 4 shows that the target population is 286 teachers and head of studies. According to the formula provided by Yamane (cited in Kasunic 2005), the table also shows that the sample size of this study was 167 teachers and head of studies in Nyarugenge district form 10 targeted secondary schools which have concurrently ordinary and advanced levels, and their results were released in the last five years (2008-2012). The sample was therefore 10 head of studies and 157 teachers from those schools.

\section{Data Collection Instruments}

Data were collected using the following techniques: questionnaires and document analysis.

\section{Pilot Study}

A pilot was carried out in two secondary schools that had the same characteristics as the sampled schools to determine the validity and reliability of the research instruments. The researcher went to the field and administered 10 questionnaires, 2 to head of studies and 8 to teachers. The responses were collected and analysed. After two weeks the same exercises was repeated and responses were again collected and analysed. After that some corrections have been made on the questionnaire. This involved pre-testing of research tools and the purpose was to identify the weakness, and deletion of ambiguity and errors before finalising research instruments to be used.

\section{Validity of the Instruments}

Construct validity was based on to ensure that questionnaires are valid. After this exercise the answered questionnaires were collected and checked for completeness by supervisor and experts in the study. Conditions for validity of the instruments were as follows, questions were worded to mean the same as to elicit reliable 
answer, cooperation between respondents and researcher was enhanced by carefully structuring interview questions, ethical research considerations and principles (beneficence, right, and justice) were guide for the research, and the research methodology will also be replicable and obtain the same results.

\section{Reliability of Instruments}

Reliability was done to measure the relevance of the tools like questionnaires and this was achieved through a pilot study where the researcher first tested and retested the questionnaires with at least ten members from the main respondents in secondary schools before going into data collection. Conditions for reliability of the instruments were the following: questions to be the same and understood in the same way, interview instructions to be the same, the sample designed was repeated, and the actual change in factors being studied may occur. The reliability of instruments was further measured by using the Spearman-Brown prophecy formula (shown below) used to predict the anticipated reliability of a longer (or shorter) test given a value of Cronbach's alpha for an existing test (Wells \&Wollack, 2003). The estimated reliability of this study was 0.8 .

\section{Data Analysis Procedures}

The analysis of data in this study required a number of closely related operations such as establishment of categories, the application of these categories to raw data through coding, tabulation and then drawing statistical conclusions. The unwieldy data were necessarily condensed into a few manageable groups and tables for further analysis. Thus, data were classified into the raw data into some purposeful and usable categories. Coding operation was done at this stage through which the categories of data are transformed into symbols that may be tabulated and counted. Editing improved the quality of the data for coding. With coding the stage was ready for tabulation. Tabulation is a part of the technical procedure wherein the classified data are put in the form of tables. The mechanical devices can be made use of at this juncture. Descriptive statistics were used to obtain the frequencies, and percentages. A great deal of data was tabulated by the computers using Statistical Package for Social Sciences (SPSS) software; and drawing statistical analysis by the same software.

\section{Description of the Population}

XII. FINDINGS

This study was carried out in 10 Nyarugenge secondary schools among 14 secondary schools that are found in Nyarugenge District. The schools involved in this study were private and public secondary schools that have the marks released from 2008 to 2012. The respondents involved in this research were 165 teachers and 10 deputy head in charge of studies.

\section{Academic Qualifications of Teachers and Head Of Studies}

The first objective of the study was to find out the ratio of qualified teachers to unqualified ones in secondary schools in Nyarugenge District and their contribution to the students' academic performance.

Table1. Qualification of teachers

\begin{tabular}{lrr}
\hline Education level & Frequency & Percent \\
\hline A2 & 6 & 4 \\
A1 & 38 & 25 \\
A0 & 106 & 68 \\
PGD & 5 & 3 \\
Total & 155 & 100 \\
\hline
\end{tabular}

Source: researcher

The table1 shows that the highest representation of respondents $68 \%$ were bachelor holders in general, and $25 \%$ of teachers are diploma holders; $4 \%$ were diploma holders, and the lowest representation were $3 \%$. The table1 shows that the majority of teachers were qualified to be secondary school teachers. However, $29 \%$ of teachers were found unqualified to be teaching in secondary schools which means that there is a requirement for school and district to organize in-service education programmes to raise the level of teachers in order to boost students' academic performance.

The Types of In-Service Education

Table 2. Types of in-service education for teachers in secondary schools

\begin{tabular}{|l|r|r|}
\hline $\begin{array}{l}\text { Types of In-service } \\
\text { education }\end{array}$ & Frequency & Percent \\
\hline in-service education & 67 & 43 \\
\hline training & 29 & 19 \\
\hline
\end{tabular}




\begin{tabular}{|l|r|r|}
\hline workshop & 17 & 11 \\
\hline coaching & 4 & 3 \\
\hline on-job training & 11 & 7 \\
\hline mentoring & 2 & 1 \\
\hline peer observation & 14 & 9 \\
\hline nothing & 11 & 7 \\
\hline Total & 155 & 100 \\
\hline
\end{tabular}

Source: researcher

According to the teachers' responses, the table2 illustrates that the majority (43\%) of schools had undergone in-service teachers' education programmes, $30 \%$ confirmed that their schools had organised training and workshop programmes, $1 \%$ were having mentoring programmes, while $7 \%$ did not attended any types of inservice teachers' education programmes in their schools. The in-service education programmes for secondary school teachers had been implemented at $70 \%$ of workshops and training. On the other hand some types of inservice education programmes such as coaching, mentoring, peer observation, which could help teachers to improve on their practices and raise students' academic performance they were not strengthened and emphasized in secondary schools.

Table 3. Needs for teachers to be continuously trained

\begin{tabular}{|c|c|c|}
\hline $\begin{array}{l}\text { Needs for teachers } \\
\text { to be trained }\end{array}$ & Frequency & Percent \\
\hline Agree & 140 & 90 \\
\hline disagree & 15 & 10 \\
\hline Total & 155 & 100 \\
\hline
\end{tabular}

The table 3 indicates that $90 \%$ of teachers who responded agreed that there is a great need of being trained at work place to update their skills and upgrade the academic qualifications; $10 \%$ disagreed that there is no need to be trained at work place or attend in-service education programmes for teachers. In the line with the teachers' responses, the overwhelming majority of teachers had a will to continuously attend in-service education programmes which could be advantageous to the school management, district and the Ministry of Education for organising in-service education programmes for secondary school teachers.

\begin{tabular}{lrr} 
Table 4. In-service education outcomes for teachers between & $\mathbf{2 0 0 8}$ and 2012 school year \\
\hline In-service education outcome & Frequency & Percent \\
\hline updating skills & 60 & 39 \\
upgrading level & 14 & 9 \\
raising teacher performance & 8 & 5 \\
improve students' performance & 11 & 7 \\
improve class practices & 8 & 5 \\
all answers are true & 54 & 35 \\
Total & 155 & 100 \\
\hline
\end{tabular}

The table 4 shows that $39 \%$ of teachers who attended in service education agreed that in-service education programmes for teachers had the major outcome to update the skills of teachers, and 35\% agreed that all the answers (updating skills, upgrading level, rising students performance, improve class practices) are true; $11 \%$ agreed that the in-service education programmes for teachers raise the teachers' performance and the students' academic performance in national examination between 2008 and 2012 school years. As discussed above, $74 \%$ of teachers agreed that in-service education programmes implemented in secondary schools were teacher-oriented and designed to improve on teachers' performance; whereas $11 \%$ agreed that in-service education programmes were designed to raise students' academic performance in national examination between 2008 and 2012. This demonstrated that the school should continue to purpose the students' academic performance strategies in the in-service training offered to teachers. 


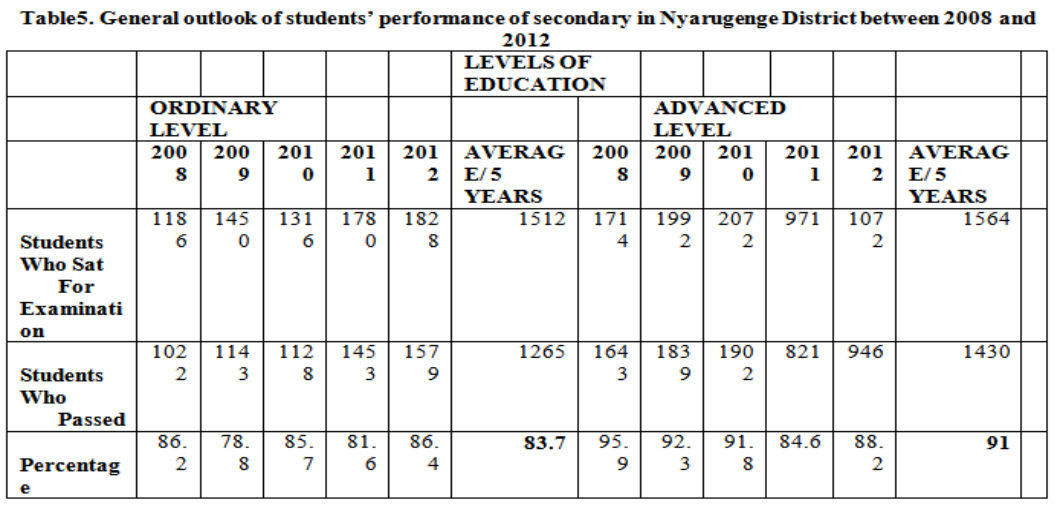

Source: Rwanda Education Board

The table5 illustrates the students' academic performance of Nyarugenge District between 2008 and 2012 school academic years in ordinary (O' level) and advanced level (A' level). It also shows the numbers of students who sat for national examinations and the numbers of students who passed, and the percentage of students who passed; and the table further indicates the average of students of ordinary and advanced level who passed in 5 academic years in percentage. As shown in the table, the average in percentage in 2008 was $86.2 \%$ in Nyarugenge District ordinary secondary schools; after 4 academic years (2009-2012) the average was $83.7 \%$. Consequently, the results revealed that the students' performance in ordinary level in Nyarugenge District had decreased in 5 years. On the other hand, as demonstrated in the table above, the average of students' academic performance of advanced level in Nyarugenge District in academic year 2008 was 95.9\%; after 4 academic years (2009-2012), the average of students had been 91\%. The table therefore shows that the students' academic performance average had declined. The in-service education programmes implemented had not significantly affected students' academic performance because they were teacher-oriented instead of being students' academic performance oriented.

\section{CONCLUSION OF THE STUDY}

Basing on the findings of this study, it was found out that the in-service educational programmes have not been effectively and regularly implemented in all secondary schools in Nyarugenge District in the last five years (2008-2012). In addition, the study found that in-service education programmes for secondary school teachers were teacher-oriented. It was found out that in-service education programmes for secondary school teachers organised by schools, district and the Ministry of Education had raised the levels and qualifications of teachers in secondary schools not the academic performance. It was therefore found that the students' academic performance in Nyarugenge district has decreased during the last five years (2008-2012). The study also found out that there is an impact of the low level of in-service education programmes implementation for teachers in secondary schools on students' academic performance. There is a need to continue to raise the level of unqualified teachers in secondary schools in order to raise the students' academic performance

\section{RECOMMENDATIONS}

The study confirmed that the ineffective in-service education programmes for secondary school teachers lead to the lowest students' academic performance and the ratio of unqualified teachers' greatly impact on the students' academic performance. Therefore, basing on the generalization of the findings of this study the researcher made the following recommendations: The Ministry of education and the district education management should design and provide a policy guide line to all secondary schools that shows how in-service education programmes should be implemented in secondary schools to raise students' academic performance. The Ministry of Education and district administration should encourage less expensive forms of in-service education like peer observation among teachers, demonstration, coaching and mentoring which are ignored by some schools. The district and schools should also reduce the number of unqualified teachers in secondary schools by continually increasing in-service education programmes in all secondary schools. Lastly, the Ministry of Education and schools should equip school libraries and laboratories with updated materials in each domain to raise students' academic performance in secondary schools as well as teachers' performance.

\section{REFERENCES}

[1] Abiddin, N.Z. (2006). Mentoring and Coaching: The Roles and Practices. The Journal of Human Resource and Adult Learning, November 2006, University Putra Malaysia, Malaysia. 
[2] Adeyemo, S.A. (2012). The Influence of Teachers' Supply and the Provision of Laboratory Facilities onStudents' Achievement in Physics. European Journal of Educational Studies, 4(3), 397.

[3] Agharuwhe, A. A., \& Ugborugbo, M.N. (2009). Teachers' Effectiveness and Students' Academic Performance in Public Secondary Schools in Delta State, Nigeria. Study Home Communication Science, 3(2), 107-113.

[4] Ajayi, I.A., \& Yusuf, M.A. (2009). Instructional Space Planning and Students' Academic Performance in South West Nigeria Secondary Schools. International Journal of Education and Science, 1(2), 73-77

[5] Akinfe , E. ,Olofinniyi, O.E., \& Fashiku, C.O. (2012). Teachers' Quality as Correlates of Students Academic Performance in Biology in Senior Secondary Schools of Ondo State, Nigeria .Online Journal of Education Research, 1(6), 108-114. Retrieved December 27, 2012, from http://www.onlineresearchjournals.org/IJER

[6] Akinsolu, A.O. (2010). Performance in Nigerian Secondary Schools:Implications for Planning. Florida Journal of Educational Administration \& Policy Summer, 3(2), 86.

[7] Al Jishi, H.A. (2009). Motivation and its Effect on Performance on Nurses in Aramco Health Center. (Master of Business Administration and Human Resources, Open University Malaysia, 2009).

[8] Ary, D., Cheser, L. J., \& Sorensen, C.K. (2010). Introduction to Research in Education (8 ${ }^{\text {th }}$ ed.). Wadsworth: Cengage Learning Bailey, D.K. (1978). Methods of Social Research. New York: Macmillan.

[9] Ball, D. L., \& Cohen, D. K. (1999). Developing Practices, Developing Practitioners: Toward a Practice-based Theory of Professional Development. In G. Sykes \& L. Darling-Hammonds (Eds.).Teaching as the learning profession: Handbook of policy and practice (pp. 30-32). San Francisco CA: Jossey-Bass.

[10] Bullock, C.C. (2007).The Relationship between School Building Conditions and Student Achievement at the Middle School Level in the Commonwealth of Virginia. (Docotral Dissertation, the Virginia Polytechnic Institute and State University ,2007)

[11] Byrne, J., Brown, H., \& Challen, D. (2000). Peer Development as an Alternative to Peer Observation: a Tool to Enhance Professional Development .International Journal for academic development, 10 (10), 1

[12] Carter, S., \& Shelton, M. (2009). The Performance Equation - What makes truly great, Sustainable Performance. Apter Development LLP . Retrieved December 27, 2012, from http://www.apterinternational.com/articles/PerformanceEquationArticle060.pdf

[13] Casteel, C.J., \& Ballantyne, K.G. (Eds.). (2010). Professional Development in Action: Improving Teaching for English Learners. Washington, DC: National Clearinghouse for English Language Acquisition. Retrieved December 28, 2012, from http://www.ncela.gwu.edu/files/uploads/3/PD_in_Action.pdf

[14] Cohen, D. K., \& Hill, H. C. (2000). Instructional Policy and Classroom Performance: The Mathematics Reform in California. Teachers College Record, 102(2), 294-343.

[15] Colbert,J.A, Brown, R.S, Choi, S.H.,\& Thomas, S. (2008) . An Investigation of the Impacts of Teacher-Driven Professional Development on Pedagogy and Student Learning. Teacher education quarterly, spring 2008.

[16] Collis, J., \& Hussey, R. (2003). Business Research ( $2^{\text {nd }}$ ed. Palgrave). New York: Macmillan.

[17] Cowie, D. (2010). Coaching for Improving Teacher Practice within a Professional Development Initiative. (Master of Educational Leadership and Management ,Unitec Institute of Technology New Zealand, 2010).

[18] Dahar, M.A. (2011). Effect of the Availability and the Use of Science Laboratories on Academic Achievement of Students in Punjab (Pakistan) .European Journal of Scientific Research, 51(2), 193-202. Retrieved December 24, 2012, from http://www.eurojournals.com/ejsr.htm

[19] Dahar, M.A., Dahar, R.A., Dahar, R.T., \& Faize , F.A. (2011). Impact of Teacher Quality on the Academic Achievement of Students at Secondary Stage in Punjab (Pakistan).European Journal of Social Sciences, 19(1), 98, 99,

[20] Davys, D., McKenna, J., \& Tickle, E. (2008). Peer Observation in Professional Development: Occupational Therapists' Perceptions .International Journal of Therapy and Rehabilitation, 15(6), 246

[21] Dilworth, M.E., \& Imig, D.G. (1995). Reconceptualizing Professional Teacher Development. The ERIC Review, 3(3), 5-11.

[22] Fakeye, D.O. (2012). Teachers' Qualification and Subject Mastery as Predictors of Achievement in English Language in Ibarapapa Division of Oyo State .Global Journal of Human Social Science, 12 (3), 1

[23] Farmer, L.S.J. (2006). Library Media Program Implementation and Student Achievement. Journal of Librarianship and Information Science, 38(1), 21-32.

[24] Gupta, A., \& Kashiri, R. (2006). Professional Development Workshops in Science Education for Teacher Capacity Building. Electronic Journal of Literacy through Science, 6 (1), 3. Retrieved December 21, 2012 form http://ejlts.ucdavis.edu

[25] Hanover, R. (2012). Effects of Peer Teacher Observation and Coaching on Student Achievement. District Administration Practice. Retrieved December 21,2012 form http://www.hanoverresearch.com

[26] Hassel, E. (1999). Professional Development: Learning from the Best a Toolkit for Schools and Districts based on the National Awards Program for Model Professional Development. Oak Brook, Illinois:The North Central Regional Educational Laboratory

[27] Kasunic, M. (2005). Designing an Effective Survey. Carnegie Mellon University.

[28] Kinkead, S. (2007). Improving Instruction through Coaching. Washington: The Center for Strengthening the Teaching Profession (CSTP)

[29] Koontz, H., \& Weihrich, H .(1988). Management. New York:McGraw-Hill, INC.

[30] Lancaster University. Peer Observation of Teaching - Briefing Paper

[31] Lofthouse, R., Leat, D., \& Towler, C. (2010). Coaching for Teaching and Learning: a Practical Guide for Schools Guidance Report .CfBT Education Trust. Retrieved December 21, 2012, from http://www.cfbt.com 
[32] Lonsdale, M. (2003). Impact of School Libraries on Student Achievement: a Review of the Research Report for the Australian School Library Association. Camberwell Victoria :Australian Council for Educational Research

[33] Lunenburg, F.C (2011). Expectancy Theory of Motivation: Motivating by Altering Expectations. International Journal of Management, Business, and Administration, 15(1), 1-4.

[34] Martha, K. (2005). Factors Affecting Academic Performance of Undergraduate Students at Uganda Christian University. (Master of Arts in educational management, Makerere University, 2005)

[35] Mednick, A. (2004). Teachers Working Together to Improve Instruction. Center for collaborative education, 4(2), 11

[36] Ministry for Public Service and Labour. (2009). National Skills Audit Report. Kigali: MIFOTRA

[37] Ministry of Education. (2006). Education Sector Strategic Plan 2006 - 2010. Kigali: MINEDUC

[38] Ministry of Education . (2010). Education Sector Strategic Plan 2010 - 2015. Kigali: MINEDUC

[39] Ministry of Education. (2012). Rwanda Education Statistics Report. Kigali: MINEDUC

[40] Mizell, H. (2010). Why Professional Development Matters. United States of America: Learning. Retrieved January 12, 2012 form www.learningforward.org/advancing/whypdmatters.cfm

[41] Moulton, J. (1997). How Do Teachers Use Textbooks? A Review of the Literature. Office of Sustainable Development Bureau for Africa, Technical Paper, 74, p.72

[42] Mundry, S. What Experience has taught us about Professional Development. Facilitating Mathematics and Science Reform: Lessons Learned. National Network of Eisenhower Regional Consortia and Clearinghouse.usa U.S. Department of Education

[43] Nakpodia, E. D. (2010). Human Resource Management in School Administration in Delta State, Nigeria. Journal of Social Sciences, 23(3), 179-187

[44] Naz, A., Khan, W., Daraz, U., Rehman, H., Hussain, M., Ibrahim, \& Alam, H. (2013). Assessing the Consequential Role of Infrastructural Facilities in Academic Performance of Students in Pakistan. International Journal Social Science \& Education, 3(2), 464

[45] Ngala, F.B.J.A., \& Odebero, S.O. (2010). Teachers' Perceptions of Staff Development Programmes as It relates to Teachers' Effectiveness: A study of Rural Primary Schools in Kenya. Academic Journals: Educational Research and Review, 5 (1), 1-9. Retrieved December 20, 2012 from http://www.academicjournals.org/ERR2

[46] Office of the Education Ombudsman. The Family Dictionary of Education Terms: Second Edition 2010 -2011. Governor's Office / State of Washington. Retrieved December 28, 2012, from http://www.waparentslearn.org

[47] Olaniyan, D. A., \& Ojo, L. B. (2008). Staff Training and Development: A Vital Tool for Organisational Effectiveness. European Journal of Scientific Research, 24(3), pp.326-331. Retrieved December 20, 2012, from http://www.eurojournals.com/ejsr.htm

[48] Owoeye, J.S., \& Yara, P.O.(2011). School Facilities and Academic Achievement of Secondary School. Asian Social Science, 7(7), 64. Retrieved December 28, 2012, from www.ccsenet.org/ass

[49] Pennsylvania State Education Association Education Services Division. (2008).Keys to Close Achievement Gaps :Planning High-Quality Professional Development. Harrisburg: Pennsylvania State Education

[50] Association Rahman, F., Jumani, N.B, Akhter ,Y., Chisthi ,S.H., \& Ajmal ,M.(2011). Relationship between Training of Teachers and Effectiveness Teaching. International Journal of Business and Social Science, 2(4),150-155.

[51] Reitzug, U.C. \& O' Hair, M. J. From Conventional School to Democratic School Community: The Dilemmas of Teaching and Leadership," in School as Community: From Promise to Practice, ed. Gail Furman-Brown (New York: State University of New York Press, in press). Sparks: Stein.

[52] Robinson M.H. (2011).Middle School Teachers' Perceptions of Professional Development Experiences. (Degree of Doctor of Education, Western Carolina University, 2011).

[53] Seton, C.L. (2005). Evaluating the Impact of Professional Development. The Journal of Research in Professional Learning. Published by the National Staff Development Council. Retrieved December 27, 2012, from www.nsdc.org

[54] Shah, P.M.A. (2009). Impact of Teacher's Behaviour on the Academic Achievement of University Students Syed Shafqat. (Doctoral dissertation in Education Arid Agriculture University, Rawalpindi, Pakistan, 2009).

[55] Sinclair-Tarr, S., and Tarr J.W. (2007). Using Large-scale Assessments to Evaluate the Effectiveness of School Library Programs in California. Phi Delta Kappan, 88(9), 710.

[56] Smith, M.S. (2008). School Building Quality and Student Performance in South Carolina Public high schools: A Structural Equation Model. (Doctoral dissertation, Clemson University, 2008).

[57] Snow-Renner, R., \& Lauer, P.A. (2005).Professional Development Analysis. Denver: Mid-continent Research for Education and Learning. Retrieved January 2, 2013, from http://www.mcrel.org

[58] Sparks, D. (2002). Designing Powerful Professional Development for Teachers and Principals. Oxford, OH: National Staff Development Council.

[59] Sparks, D. and Hirsh, S. (2000). A National Plan for Improving Professional Development. ERIC, ED 442779

[60] Srivastava, R.,\& Joshi, S. (2011). The Effect of School and Area on Academic Self-Concept and Academic Achievement of Adolescents. Delhi psychiatry journal, 14(2), 331-335.

[61] Suleman, Q., Aslam, D.H., Sarwar, S., Lodhi, M.A.,\& Hussain, I. (2012). Factors Responsible for Unsatisfactory Academic Performance of the Secondary School Students in the Rural Areas of Kohat Division, Khyber Pukhtunkhwa (Pakistan) . American Journal of Scientific Research, 43, pp. 46-57. Retrieved January 21, 2013, from http://www.eurojournals.com/ajsr.htm

[62] Sullivan, H.G. (2008). An Investigation of a Professional Development Program Using Industry Partnerships and Student Achievement. Doctoral dissertation, Texas A\&M University,2008)

[63] Taylor, C., \& Francis, G. (2011). Mentoring \& Tutoring: Partnership in Learning, 19(3), 347-364. Retrieved January 21, 2013, from http://www.informaworld.com 
[64] The Finance Project and Public Education Network (PEN). Teacher Professional Development: A Primer for Parents and Community Members. Retrieved on January 20, 2013 from http://www.PublicEducation.org

[65] The World Bank. (2004). A World Bank Country study: Education in Rwanda Rebalancing Resources to Accelerate Post-Conflict Development and Poverty Reduction. Washington, D.C.: The International Bank for Reconstruction and Development / The World Bank

[66] Thomas, O.O., \& Olugbenga, A.J . (2012). Effect of Teacher's Qualification on the Performance of Senior Secondary School Physics Students: Implication on Technology in Nigeria . Canadian Center of Science and Education: English Language teaching, 5(6),72. Retrieved December 28, 2012, from http://www.ccsenet.org/elt

[67] Todd, R. J., (2003). Student Learning Through Ohio School libraries: A Summary of the Ohio Research Study. Ohio Educational Library Media Association (OELMA). Retrieved January19, 2013, from http://www.oelma.org/StudentLearning/documents/OELMAResearchStudy8page.pdf

[68] Tope, O. (2013). Influence of School Environment on Students' Performance of Secondary School Lagos State . Ogun State, Nigeria: EgoBooster Books. Vandiver, B. (2011). The impact of School facilities on the Learning Environment. (Doctoral dissertation, Capella University,2011)

[69] Villegas-Reimers , E. (2003). Teacher Professional Development: An International Review of the Literature. Paris: UNESCO: International Institute for Educational Planning

[70] Wei, R. C., Darling-Hammond, L., Andree, A., Richardson, N.,\& Orphanos, S. (2009). Professional Learning in the Learning Profession: A Status Report on Teacher Development in the United States and Abroad. Dallas, TX: National Staff Development

[71] Wells, C. S., \& Wollack, J.A. (2003). An Instructor's Guide to Understanding Test Reliability. Testing \& Evaluation Services: University of Wisconsin

[72] Wong, K., \& Nicotera, A. (2003). Enhancing Teacher Quality: Peer Coaching as a Professional Development Strategy, Publication Series No. 5 .Vanderbilt University

[73] Yara, O.P., \& Otieno, K.O. (2010).Teaching/Learning Resources and Academic Performance in Mathematics in Secondary Schools in Bondo District of Kenya. Asian Social Science, 6(12), 126. Retrieved on January 20, 2013, from http://www.ccsenet.org/ass

[74] Yoon, K. S., Duncan, T., Lee, S. W.-Y., Scarloss, B., \& Shapley, K. (2007). Reviewing the Evidence on how Teacher Professional Development Affects Student Achievement (Issues \& Answers Report, REL 2007-No. 033). Washington, DC: U.S. Department of Education, Institute of Education Sciences, National Center for Education Evaluation and Regional Assistance, Regional Educational Laboratory Southwest. Retrieved January 28, 2013, from http://ies.ed.gov/ncee/edlab 